\title{
JAMINAN AKSES INFORMASI DALAM PERLINDUNGAN DAN PENGelolaAN LiNGKUNGAN HiduP (REKOMENdAsi PENGUATAN HAK AKSES INFORMASi LingKungan)
}

Henri Subagiyo ${ }^{1}$

\begin{abstract}
Abstrak
Demokrasi deliberatif dalam pengelolaan dan perlindungan lingkungan hidup mensyaratkan adanya partisipasi masyarakat dalam menjawab kompleksitas lingkungan dan post-normal science. Untuk mencapai partisipasi yang ideal, akses masyarakat terhadap informasi lingkungan harus terpenuhi. Namun berbagai pembelajaran dari praktek menunjukkan bahwa implementasi akses informasi lingkungan yang telah ada saat ini masih jauh dari ideal. Tulisan ini mencoba menelaah secara normatif kekurangan-kekurangan yang ada dari kerangka hukum akses informasi lingkungan yang telah ada sekarang, baik dari sudut pandang hukum lingkungan maupun keterbukaan informasi. Lebih jauh, tulisan ini menyajikan pula beberapa alternatif yang dapat dilakukan untuk memperbaiki norma akses informasi lingkungan agar dapat lebih memfasilitasi partisipasi masyarakat dalam pembuatan hukum ke depannya.

Kata kunci: akses informasi, informasi lingkungan, Prinsip 10 Rio, demokrasi deliberatif
\end{abstract}

\section{Abstract}

Deliberative democracy in environmental management and protection requires public participation in answering the environmental complexity and post-normal science. To achieve ideal participation, community access to environmental information shall be fulfilled. However, some lesson from the practice show that the current implementation of access to environmental information is still far from ideal. This Article tries to study normatively the weaknesses in the existing legal framework of environmental information access, either from the perspective of environmental law and information openness. Moreover, this Article also serve some alternatives that can be done to

${ }^{1}$ Penulis adalah Direktur Eksekutif Indonesian Center for Environmental Law (ICEL) 
improve the access to environmental information norms so it can further facilitate community participation in the lawmaking ahead.

Keywords: access to information, environmental information, Principle 10 Rio, deliberative democracy

\section{Latar Belakang}

Sumber daya alam merupakan salah satu penopang utama pembangunan nasional. Sebagai penopang pembangunan, rata-rata $70 \%$ pendapatan negara bersumber dari pemanfaatan sumber daya alam. ${ }^{2}$ Di sisi lain, pemanfaatan sumber daya alam yang belum memperhatikan perlindungan daya dukung dan daya tampung lingkungan hidup seringkali berdampak pada timbulnya perusakan atau pencemaran lingkungan hidup. Perusakan dan pencemaran lingkungan hidup tersebut menimbulkan kerugian bagi masyarakat, tidak hanya masalah lingkungan, melainkan juga masalah kesehatan maupun kualitas hidup yang lebih baik.

Perusakan dan pencemaran lingkungan hidup seringkali terkait dengan lemahnya akses masyarakat terhadap informasi, baik tentang perubahan kondisi lingkungan hidup yang dihadapinya, seperti polutan yang berpengaruh pada kesehatan, maupun pada tingkat pengambilan keputusan yang berpengaruh pada masyarakat, baik yang bersifat umum maupun teknis seperti pemberian izin usaha/kegiatan. ${ }^{3}$

Pada tataran praktek, pemenuhan akses informasi di bidang perlindungan dan pengelolaan lingkungan hidup belum menunjukkan hasil yang menggembirakan. Hal ini terungkap dari hasil uji akses terhadap informasi lingkungan yang telah dilakukan kelompok masyarakat terdampak pencemaran lingkungan di DAS Sungai Ciujung Banten dan PLTU Tanjung Jati, Jepara dengan pendampingan Indonesian Center for Environmental Law (ICEL). Dari total 44 permohonan informasi lingkungan yang bersifat penting (Analisa mengenai dampak lingkungan (Amdal), Izin Lingkungan, Hasil Monitoring Kualitas Lingkungan) kepada Pemerintah dan Pemerintah Daerah, hanya 10 permohonan yang dikabulkan, 11 permohonan dikabulkan setelah keberatan

${ }^{2}$ Kementerian Keuangan, Nota Keuangan Tahun 2012.

3Prayekti Murharjanti, et.al., Menutup Akses Menuai Bencana (Potret Pemenuhan Akses Informasi, Partisipasi, dan Keadilan dalam Pengelolaaan Lingkungan Hidup dan Sumber Daya Alam di Indonesia), Cet. I, (Jakarta: ICEL, 2008), hal. 27. 
internal, dan 23 permohonan tidak dikabulkan dengan pendiaman (mute refusal). ${ }^{4}$

Jaminan hukum tentang akses informasi sebetulnya sudah ada dalam hukum nasional kita. Undang-Undang Nomor 32 Tahun 2009 tentang Perlindungan dan Pengelolaan Lingkungan Hidup (UU PPLH) mengatur dua prinsip penting yang terkait dengan akses informasi, yaitu: (a) tata kelola pemerintahan yang baik; dan (b) partisipatif. ${ }^{5}$ UU PPLH menjelaskan bahwa prinsip tata kelola pemerintahan yang baik harus dijiwai oleh prinsip partisipasi, transparansi, akuntabilitas, efisiensi, dan keadilan. Lebih jauh lagi, terkait prinsip partisipasi UU PPLH menjelaskan bahwa setiap anggota masyarakat harus didorong untuk berperan aktif dalam proses pengambilan keputusan, baik secara langsung maupun tidak langsung. ${ }^{6}$ Selain UU PPLH, pengaturan khusus tentang pemenuhan akses informasi juga ditemukan dalam Undang-Undang Nomor 14 Tahun 2008 tentang Keterbukaan Informasi Publik (UU KIP).

Jaminan atas informasi juga sudah dikenal dalam berbagai instrumen hukum internasional. Monterrey Consensus yang dihasilkan dari Konferensi Internasional tentang Keuangan untuk Pembangunan pada tahun 2002 menyatakan bahwa good governance adalah esensi dari pembangunan berkelanjutan. Selain itu, The United Nations Millennium Declaration menyatakan: "if we are to capture the promises of globalization while managing its adverse effects, we must learn to govern better, and we must learn how better to govern together." 7 Governance didefinisikan sebagai "the set of values, policies, and institutions by which a society manages economic, political, and social processes"8; sebagai "the manner in which power is exercised in the management of a country's economic and social resources for development"9; dan sebagai "the process of decision making and the process by which decisions are implemented"10. Selain itu, governance juga diartikan

4Indonesian Center for Environmental Law (ICEL), “Catatan Akhir Tahun 2011”, (Jakarta: ICEL, 28 Desember 2011), hal. 4.

Indonesia (a), Undang-Undang tentang Perlindungan dan Pengelolaan Lingkungan Hidup, UU Nomor 32 Tahun 2009, LN No. 140 Tahun 2009, TLN No. 5059, Ps. 2.

${ }^{6}$ Ibid, Ps. 2 huruf $\mathrm{k}$ dan $\mathrm{m}$.

${ }^{7}$ Kofi A. Annan, We the People: the Role of the UN in the 21 $1^{\text {st }}$ Century, http://iefworld.org/UNSGmill.htm, diakses pada tanggal 4 November 2012

${ }^{8}$ G. Shabbir Cheema, "Good Governance: A Path to Poverty Eradication", Choices: The Human Development Magazine, No. 1, March 2000, hal. 6 - 7.

${ }^{9}$ World Bank, Governance Development, http://publications.worldbank.org/index.php?main_page=product_info\&cPath=\&products_ $\underline{\mathrm{id}=20725}$, diakses pada tanggal 4 November 2012.

10UNESCAP, What is Good Grnance?, http://www.unescap.org/huset/gg/governance.htm, diakses pada tanggal 6 Mei 2012. 
sebagai "the framework of rules, institutions, and practices that set limits and provides incentives for the behaviour of individuals and organizations"11. Berdasarkan definisi diatas, governance bukan hanya sekedar pemerintah melainkan termasuk interaksi antar berbagai pihak atau aktor.

The United Nations Economic and Social Commission for Asia and the Pacific (UNESCAP) mengidentifikasi beberapa prasyarat utama good governance, di antaranya transparansi, partisipasi, equity, inkusifitas, dan rule of law. ${ }^{12}$ Masyarakat internasional berulang kali menunjukkan ketiadaan prasyarat tersebut sebagai alasan dari kegagalan untuk mengatasi masalah-masalah pengentasan kemiskinan, pembangunan manusia, dan masalah sosial serta lingkungan. ${ }^{13}$ Penjelasan di atas memperkuat pendapat bahwa transparansi, partisipasi, dan akuntabilitas adalah esensi dalam mewujudkan pembangunan berkelanjutan.

Pengaturan lebih rinci tentang 3 Akses dapat ditemukan dalam the United Nations Economic Commission for Europe (UNECE) Convention on Access to Information, Public Participation in Decision-Making and Access to Justice in Environmental Matters atau lebih popular disebut Konvensi Aarhus (Aarhus Convention) yang ditandatangani pada tanggal 25 Juni 1998 di Kota Denmark, Aarhus. Konvensi ini mulai berlaku pada tanggal 30 Oktober 2001. Pada bulan Juli 2009, Konvensi ini telah ditandatangani oleh 40 Negara (terutama Eropa dan Asia Tengah) dan Uni Eropa serta telah diratifikasi oleh 41 negara. ${ }^{14}$

Tulisan ini hendak menganalisa bagaimana pemenuhan hak atas informasi lingkungan dalam hukum nasional kita dengan mendasarkan pada persoalan-persoalan hukum yang ada serta bagaimana rekomendasi bagi penguatannya ke depan.

\section{Pemikiran Dasar :}

\section{Pentingnya Akses Informasi Lingkungan Hidup}

\subsection{Post Normal Science :}

\footnotetext{
${ }^{11} \mathrm{UNDP}$,

Human

Development

Report

1999, http://hdr.undp.org/en/media/HDR_1999_EN.pdf, diakses pada tanggal 6 Mei 2012, hal. 34.

${ }^{12}$ UNESCAP, loc.cit.

${ }^{13}$ Elena Petkova, et. al., "Closing the Gap: Information, Participation, and Justice in Decision Making for the Environment", http://pdf.wri.org/closing_the_gap.pdf, diakses pada 4 November 2012, hal. 14

${ }^{14}$ What is Aarhus Convention?, http://ec.europa.eu/environment/aarhus/, diakses pada tanggal 24 April 2012.
} 


\section{Kompleksitas Lingkungan serta \\ Keterbatasan Ilmu Pengetahuan dan Teknologi (Iptek) sebagai Landasan Pentingnya Partisipasi Publik}

Lingkungan hidup dan masalah yang ada di dalamnya merupakan suatu sistem yang kompleks, terdiri dari berbagai subsistem dimana masingmasing komponen yang ada di dalamnya memiliki fungsi dan perilaku yang berbeda-berbeda dan saling terkait ataupun saling menegasikan satu sama yang lainnya untuk membentuk keseimbangan. Sebagai sistem yang kompleks, maka Iptek terlalu sederhana jika digunakan untuk memecahkan permasalahan yang ada. ${ }^{15}$

Post normal science adalah suatu konsep yang dikembangkan oleh Silvio Functowicz and Jerome Ravetz yang mengkritisi tentang keterbatasan ilmu pengetahuan dalam memecahkan permasalahan yang kompleks. Sebagai contoh dalam dugaan pencemaran Teluk Buyat, untuk membuktikan apakah persoalan termoklin ada dan dapat menahan tailing agar tidak terdeposisi, mencari hubungan kesehatan masyarakat dengan kondisi lingkungan, mencari hubungan unsur $\mathrm{Hg}$ dan As dengan sumbernya membutuhkan berbagai studi yang sangat rumit dengan pendekatannya masing-masing dan bahkan berbagai studi tersebut menunjukkan hasil yang berbeda-beda pula. Kompleksitas lingkungan hidup yang sedemikian rumit tersebut tidak cukup memadai didekati atau dijelaskan dengan Iptek karena memiliki berbagai keterbatasan, antara lain: 16

Pertama, Iptek bersifat tidak pasti. Iptek merupakan hasil ciptaan manusia yang merupakan bagian kecil dari subsistem lingkungan hidup. Persoalannya, sebagai subsistem dari lingkungan hidup atau alam, Iptek tidak dapat menjawab atau menjelaskan sesuatu di luar dirinya yang lebih besar dan kompleks. ${ }^{17}$ Sifat Iptek sendiri yang selalu berkembang menunjukkan bahwa Iptek sesungguhnya penuh dengan ketidakpastian. Contoh lainnya, dulu para ilmuwan berkeyakinan bahwa chlorofuorocarbons (CFCs) tidak menimbulkan

15 Silvio Funtowics and Jerome Ravetz, "Post Normal Science: Environmental Policy Under Conditions of Complexity", University of Bergen and Oxford, Sec. 2; Lihat pula Silvio Funtowics et.al., "Information Tools for Environmental Policy Under conditions of Complexity", European Environtment Agency, 1999, hal 6.

${ }_{16}$ Silvio Functowicz and Jerome Ravetz, Post Normal Science: Environmental Policy under Conditions of Complexity, (UNSAP), hal. 2.

${ }^{17}$ Ibid. 
dampak bagi lingkungan yang kemudian akhirnya diakui sebagai suatu kesalahan karena emisi dari gas tersebut terbukti merusak lapisan ozon. ${ }^{18}$

Kedua, Iptek memiliki perspektif yang plural (kompleksitas). Iptek memiliki perspektif yang tidak tunggal sesuai dengan bidangnya masingmasing. Hal ini mengakibatkan munculnya perspektif yang beragam dalam melihat dan memecahkan suatu permasalahan. Contohnya, jika ada sekelompok orang melihat bukit, maka setiap orang akan memberikan makna dalam perspektif yang berbeda-beda. Ada yang melihatnya sebagai hutan, situs peninggalan/arkeologi, sekumpulan batu, dan sebagainya. Pada kasus Teluk Buyat, ada perbedaan sudut pandang antara masyarakat nelayan dan PT. NMR. Masyarakat nelayan yang bergantung dengan perairan Teluk Buyat memaknai perairan tersebut sebagai wilayah kelola untuk kebutuhan perikanan sedangkan bagi PT. NMR memaknai bahwa Teluk Buyat sebagai tempat yang efisien untuk penempatan tailing di dasar laut. ${ }^{19}$

Ketiga, Iptek merupakan hasil dari suatu usaha sosial yang berlangsung lama dimana rasionalisasinya melalui proses rutinitas tahap demi tahap untuk tujuan tertentu padahal peristiwa-peristiwa yang muncul dalam permasalahan lingkungan hidup yang kompleks umumnya terjadi secara seketika dan bersifat dinamis. ${ }^{20}$ Kondisi ini menghadapkan masyarakat pada suatu resiko yang sulit untuk diprediksikan dan dapat segera dijawab oleh Iptek. Sulitnya menjawab resiko dengan Iptek bukan hanya karena persoalan Iptek saja melainkan juga perspektif resiko yang bersifat multidimensional. ${ }^{21}$ Resiko sendiri merupakan konsep yang kompleks. Resiko setidaknya memiliki dua variabel fungsi, yaitu kemungkinan dari dampak dan besarnya. Umumnya karakteristik dari resiko digambarkan dengan berbagai hal yang membutuhkan berbagai pertimbangan. Sebagai contoh di bidang energi, berbagai sumber resiko termasuk gas rumah kaca, sampah radioaktif, polutan, kebisingan, lanskap, dan sebagainya mencerminkan berbagai cara atau jalan yang berbeda-beda dengan berbagai perbedaan kondisi fisik, biologi, sosial, budaya, dan ekonomi. Oleh karena itu, pengambilan keputusan melalui pendekatan Iptek seperti cost and benefit

${ }^{18}$ Stephen R Dovers and John W Handmer dalam R. Harding and E. Fisher, "Ignorance, Sustainability and The Precautionary Principle: Towards An Analytical Framework" dalam Perspectives on the Precautionary Principle, (Sydney: The Federation Press, 1999), hal 172.

19 Amdal PT. NMR, November 1994, hal 3-37 - 3-47. Lihat pula Telaah Latar Belakang Pemilihan STP PT. NMR, Dokumen Data Arsip yang Berkaitan dengan PT. Newmont Minahasa Raya, Kementerian Lingkungan Hidup, 1994-2002.

20 Stephen Cotgrove, "Technology, Rationality and Domination", Social Studies of Science, Vol. 5(1), Feb. 1975, hal. 56-59.

21 Andy Stirling and David Gee, "Science, Precoaution, and Practice", Public Health Report, Vol. 117, Nov-Des 2002, hal. 521-522. 
analysis akan mereduksi hal-hal yang penting dari suatu resiko. Dalam banyak hal teknik dari cost and benefit analysis banyak memaksakan pertimbangan moneter untuk menjelaskan tentang dampak untuk kemudian dibandingkan dengan manfaatnya. ${ }^{22}$

Keempat, Iptek tidak netral atau bebas nilai. Iptek mendapatkan campur tangan manusia melalui proses yang cukup panjang bahkan berabad-abad secara rutin dan bertahap yang dipengaruhi oleh budaya dan peristiwa yang terjadi. Secara tidak langsung Iptek juga telah melayani ideologi dominasi atas alam dimana alam harus ditaklukkan oleh manusia. ${ }^{23}$ Hal ini juga telah dibuktikan secara historis dimana keberadaan Iptek telah berkontribusi kepada tingginya resiko lingkungan yang semakin meningkatkan kompleksitas permasalahan. Mulai pada abad industrialisasi dimana Iptek dianggap sebagai salah satu faktor produksi ternyata juga menimbulkan persoalan yang semakin kompleks bagi lingkungan hidup. Sejak ditemukan dan diproduksinya reaktor nuklir, zat kimia, organisme yang telah dimodifikasi, dan sebagainya pada satu sisi memberikan kemajuan namun pada satu sisi lain juga telah meningkatkan resiko bagi masyarakat. ${ }^{24}$ Resiko tersebut tidak mungkin diketahui atau dipastikan tanpa melalui penelitian yang berbasiskan Iptek. Oleh karena itu, lingkungan hidup telah berubah menjadi sebuah "laboratorium". Awalnya, penelitian Iptek dilakukan melalui eksperimen di laboratorium, namun dalam hal teknologi skala besar proses tersebut menjadi diputarbalikkan. Sebelum para ilmuwan dapat mempelajari tentang risiko jangka panjang dari megateknologi tersebut mereka malah terlebih dahulu dan menerapkannya dalam masyarakat luas. ${ }^{25}$ Dilihat dari strukturnya, iptek mendapatkan campur tangan manusia dan interaksinya sehingga seringkali subyektifitas atau perspektif manusia yang berbeda-beda ataupun "moral hazard" turut berpengaruh dalam melakukan analisa terhadap fenomena yang ada. Hal ini terlihat jelas dalam kasus dugaan Teluk Buyat dimana hasil semua penelitian yang dilakukan oleh PT. NMR maupun LSM memberikan kesimpulan yang berbeda-beda, masingmasing mendukung hipotesanya serta saling menegasikan satu sama lain terhadap persoalan tentang ada tidaknya pencemaran, aman tidaknya tailing,

\footnotetext{
22 Ibid, hal. 522.

${ }^{23}$ William Leiss, "Ideology and Science", Social Studies of Science, Vol. 5(2), May 1975, hal. 196.

${ }^{24}$ Frank Fischer, Citizen, Experts, and the Environment : the Politics of Local Knowledge (London: Duke University Press, 2000), hal. 48-49.

${ }^{25} \mathrm{Ibid}$, hal. 54.
} 
benar tidaknya masyarakat sakit karena pencemaran, dan sebagainya. Kondisi ini justru menempatkan manusia dalam suatu ketidakpastian. ${ }^{26}$

Kelima, Iptek dapat memicu ketegangan dan konflik dalam pemgambilan keputusan. Ketegangan dan konflik tersebut diakibatkan oleh hubungan tarik-menarik antara Iptek, politik lingkungan, dan implikasinya baik bagi politik maupun resiko dampak. Pada satu sisi Iptek diasosiasikan sebagai penyebab terjadinya kerusakan lingkungan tetapi di sisi lain juga sebagai solusi untuk melindungi lingkungan. ${ }^{27}$ Pengambilan keputusan yang teknokratis dengan pendekatan "risk-benefit analysis" saja merupakan ilustrasi adanya ketergantungan teknik pengambilan keputusan kepada Iptek. Peran ganda Iptek pada proses pengambilan keputusan ini kerap menimbulkan konflik antara para ahli dan masyarakat. Perdebatan atas resiko yang ditimbulkan oleh penerapan Iptek diangkat menjadi pertanyaan di ranah teknis atas resiko yang sesungguhnya. ${ }^{28}$ Selain proses politik yang kompleks, uang, dan kepentingan juga berperan, para ilmuwan dalam melakukan penelitian turut dipengaruhi oleh suatu desain dan pilihan yang ditawarkan oleh pemberi dana. 29

Berdasarkan kondisi tersebut, tugas pengambil kebijakan seharusnya menjadi "fasilitator" yang menggabungkan berbagai perspektif dari mereka yang memiliki minat atau kepentingan atas permasalahan yang dihadapi. Pendekatan Iptek saja akan menyederhanakan cara pandang pengambil kebijakan dalam membuat suatu keputusan yang mungkin akan berakibat negative jika terjadi kesalahan atau tidak selaras dengan perspektif orang lain dalam suatu subsistem lingkungan hidup yang kompleks. Hubungan antara ketidakpastian dan resiko atau taruhan kebijakan dapat digambarkan dalam diagram dibawah ini: ${ }^{30}$

${ }^{26}$ Ibid, hal 7.

${ }^{27}$ Frank Fischer, Science and Politics in Environmental Regulation: The Politicization of Expertise, (London: Duke Univeristy Press, 2000), hal. 108.

${ }^{28}$ Ibid, hal. 93.

${ }^{29} \mathrm{Ibid}$, hal.101.

${ }^{30}$ Silvio Functowicz and Jerome Ravetz, Op. Cit., hal.4. 


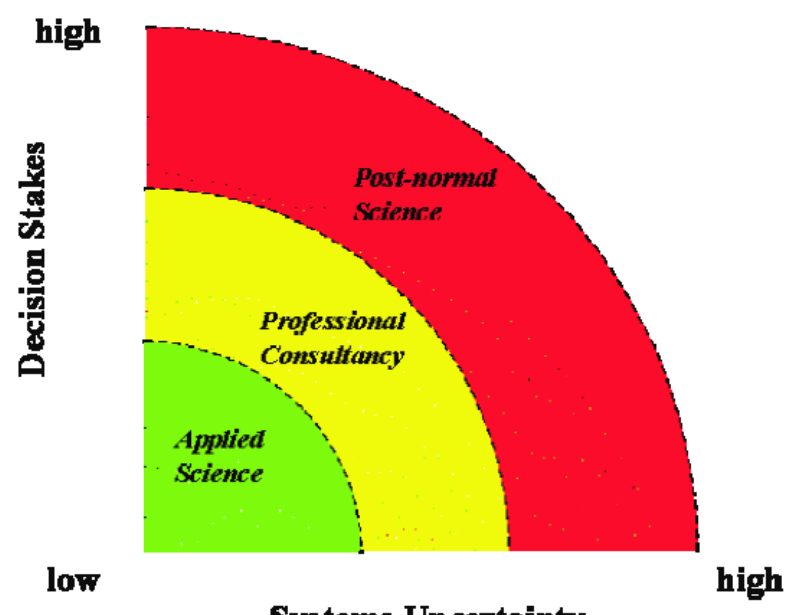

Sys tems Uncertainty

Pada diagram di atas, kita melihat dua sumbu, "ketidakpastian sistem" dan "taruhan keputusan". Ketika resiko dan taruhan kebijakan tidak terlalu besar, kita berada dalam ranah "normal", di mana keahlian dari ilmuwan dapat sepenuhnya berfungsi secara efektif. ${ }^{31}$ Semakin besar ketidakpastian, maka taruhan atau resiko kebijakan akan semakin besar dan oleh karena itu ilmu terapan tidak lagi memadahi sehingga diperlukan adanya keterampilan, penilaian, bahkan keberanian yang lebih dalam mengambil keputusan. Pada kondisi ini disebut sebagai "konsultasi profesional", misalnya dokter bedah atau insinyur senior yang akan membantu ilmuwan terapan dengan memberikan konsultasi.

Meskipun demikian, tentu saja selalu ada masalah yang tidak bisa dipecahkan oleh ilmu pengetahuan. Ketika kita menghadapi kondisi alam misalnya, kita menemukan ketidakpastian yang ekstrim yang tidak bisa diselesaikan dengan mudah padahal harus segera diambil keputusan agar permasalahan yang dihadapi dapat segera terselesaikan. Oleh karena itu dalam setiap pemecahan masalah, keputusan dari berbagai pemangku kepentingan juga harus diperhitungkan. Kontribusi dari pemangku kepentingan dalam pengambilan keputusan bukan hanya soal partisipasi demokratis yang lebih luas saja, melainkan juga sebagai peer review dalam suatu usulan kebijakan yang mungkin juga berdampak atau memiliki resiko terhadap mereka. Dengan demikian, pendekatan post normal science menawarkan suatu pendekatan yang lebih komprehensif tidak hanya sekedar pendekatan science melainkan juga

${ }^{31}$ Ibid. 
kesadaran para pemangku kepentingan terhadap keputusan yang akan diambil beserta resikonya. ${ }^{32}$

Dari kelima hal tersebut juga dapat disimpulkan bahwa penggunaan Iptek terutama yang memiliki unsur ketidakpastian ilmiah harus diiringi dengan pendekatan kehati - hatian untuk mencegah dampak besar dan permanen terhadap lingkungan. Pada akhir tahun 1980 sampai dengan awal 1990, respon atas ketidakpastian ilmiah telah mengembangkan pelembagaan dari "asas kehati - hatian (precautionary principle)". ${ }^{33}$ Pada umumnya asas kehati - hatian dirumuskan dalam pernyataan bahwa apabila terdapat ancaman kerugian yang serius atau tidak bisa dipulihkan (threats of serious or irreversible damage), pengambil keputusan tidak dapat menggunakan kurangnya kepastian atau bukti ilmiah sebagai alasan untuk menunda dilakukannya upaya pencegahan atas ancaman tersebut. ${ }^{34}$ Asas ini dalam berbagai dokumen internasional dianggap sebagai arahan (guidance) bagi pengambilan keputusan di dalam situasi ketidakpastian ilmiah. ${ }^{35}$ Penerapan asas kehati-hatian dalam pengambilan keputusan dilakukan dengan mengarah kepada proses pemecahan masalah yang deliberatif dan menggunakan berbagai disiplin ilmu. ${ }^{36}$ Dengan demikian pengambil keputusan diharapkan dapat melakukan tahap mempertimbangkan kembali setiap keputusan yang akan dikeluarkan apabila terdapat ketidak pastian ilmiah dan ancaman serius bagi lingkungan hidup.

\subsection{Partisipasi Publik: \\ Pendekatan Demokrasi Deliberatif dalam Mengatasi Kompleksitas Lingkungan dan Keterbatasan Iptek}

Adanya kompleksitas lingkungan dan keterbatasan Iptek menyebabkan keputusan lingkungan tidak cukup hanya didekati secara linier dengan pendekatan Iptek. Salah satu pendekatan penting ditengah realitas Iptek adalah dialog diantara pemangku kepentingan, terutama bagi mereka yang potensial terkena dampak untuk mengambil solusi dari permasalahan yang dihadapi. Dengan demikian, pengambilan keputusan didasari suatu kesadaran dari pemangku kepentingan akan manfaat dan resiko yang mungkin dihadapi

32 Ibid.

${ }^{33}$ R. Harding and E. Fisher, Op. Cit., hal 3.

${ }^{34}$ Andri G Wibisana, "Konstitusi Hijau Perancis: Komentar atas Asas Kehati - hatian dalam Piagam Lingkungan Perancis 2004", Jurnal Konstitusi, Vol. 8(3), Juni 2011, hal. 213 - 214. ${ }^{35}$ Ibid.

${ }^{36}$ R. Harding and E. Fisher., Op. Cit, hal. 290. 
dikemudian hari termasuk jika keputusan yang diambil tersebut pada akhirnya salah. ${ }^{37}$ Proses deliberatif menunjukkan berjalannya komunikasi antara resiko dengan temuan ilmiah. Metode ini lebih fokus kepada aspek studi psikologi untuk memecahkan masalah melalui pendekatan partisipatoris untuk membangun konsensus. ${ }^{38}$

Pelibatan pihak yang berkepentingan dan terkena dampak tidak hanya untuk mengurangi ketidaktahuan, tetapi juga untuk mengakomodasi ambiguitas intrinsik dalam framing ilmu resiko. Masyarakat terkena dampak yang menyadari efek dari suatu rencana atau kegiatan juga dapat memberikan informasi bagi pengambil keputusan sehingga meningkatan kualitas keputusan yang akan atau telah diambil. ${ }^{39} \mathrm{Hal}$ ini sesuai dengan apa yang dikemukakan sebagai keuntungan dari menggunakan proses deliberatif dalam asas kehatihatian, dimana terdapat 2 (dua) keuntungan lainnya dari penggunaan metode tersebut yaitu:40 (1) Menjamin bahwa keputusan yang dibuat atas dasar ketidakpastian ilmiah telah dilakukan berdasarkan demokrasi yang didasarkan atas wewenang yang sah; dan (2) Menjadi sarana untuk membina kepercayaan diantara para pemangku kepentingan.

Richardson, sebagaimana dikutip oleh Sharon Beder, menjelaskan beberapa keuntungan dari partisipasi, yaitu:41 (1) Mendorong terciptanya sistem pemerintah yang fair. Pihak yang akan terkena dampak dari pengambilan keputusan harus mendapatkan hak untuk mempengaruhi keputusan; (2) Partisipasi sangat penting bagi kemaslahatan pihak yang berpartisipasi. Hal ini membantu membangun kemampuan individu dan kesadaran serta membentuk warga yang terinformasikan dan terlibat dimana hal ini sangat penting bagi demokrasi; (3) Partisipasi publik biasanya menghasilkan keputusan yang lebih baik. Dalam hal ini, partisipasi yang meningkat merupakan bentuk bantuan bagi pembuat keputusan sebab dengan hal tersebut mereka memiliki informasi mengenai pelayanan apa yang dibutuhkan, batas toleransi publik, masalah, perhatian dan isu yang ada.

Proses dialog bertujuan memberikan ruang yang memadai bagi setiap unsur untuk mengemukakan kepentingan dan kekhawatirannya sehingga menjadi pertimbangan dalam pengambilan kebijakan. Proses dialog dalam

\footnotetext{
37 Ibid, hal. 8-11.

38 Frank Fischer, Op. Cit, hal. 108.

${ }^{39}$ Andy Stirling and David Gee, Op. Cit., hal. 527.

40 R. Harding and E. Fisher., Op. Cit., hal. 293.

41 Sharon Beder, Environmental Principles and Policies, (London: Earthscan, 2006), hal.
} 120. 
pengambilan keputusan ini merupakan "terobosan" dari kritik terhadap model perwakilan (demokrasi agregatif) yang mengedepankan suara mayoritas dalam pengambilan keputusan sehingga tidak dapat sepenuhnya mengakomodir kepentingan atau kekhawatiran dari seluruh pemangku kepentingan, khususnya bagi kelompok minoritas. ${ }^{42}$

Ada tiga alasan proses pengambilan keputusan memerlukan dialog: ${ }^{43}$ (1) Agar warga dapat membahas isu-isu publik dan kesempatan beropini; (2) Agar wawasan pemimpin jauh lebih baik dalam isu-isu publik; (3) Agar orang dapat membenarkan pandangannya untuk dapat memilah baik dan buruk. Demokrasi deliberatif mengacu pada konsepsi bahwa pemerintahan yang demokratis memberikan ruang untuk diskusi secara rasional dan moral dalam suatu kehidupan politik. ${ }^{44}$ Menurut Gutman dan Thompson, teori demokrasi deliberatif terletak pada adanya kepedulian dalam membentuk kerjasama dengan alasan banyaknya konflik dan ketidaksepakatan moral dalam masyarakat. ${ }^{45}$ Sedangkan James Bohman berpendapat bahwa demokrasi menyiratkan musyawarah atau doialog: "the deliberation of citizens is necessary if decisions are not to be merely imposed upon them...consent, is after all, the mean feature of democracy". Dengan kata lain, pengambilan keputusan adalah sah sepanjang kebijakan yang dihasilkan melalui proses dialog di mana masingmasing tidak hanya sekadar mengusung kepentingannya saja melainkan juga merefleksikan kepentingan pihak lainnya demi kepentingan dan kebaikan bersama. ${ }^{46}$

Dialog mengharuskan agar para pihak meninggalkan ciri utama model demokrasi agregatif yang justru bukan untuk mencapai konsensus berdasarkan prinsip bebas dan setara. Demokrasi deliberatif menghendaki proses transformatif. Melalui proses dialog dengan pendapat yang beragam, kita sering mendapatkan informasi baru, belajar dari pengalaman yang berbeda dari masalah kolektif yang ada, bahkan dapat menyadarkan kita bahwa pendapat kita awalnya hanya didasarkan pada prasangka atau ketidaktahuan, atau bahwa mereka telah salah memahami hubungan kepentingan kita dengan orang lain. Dengan terlibat dalam dialog, kita terdorong untuk mau

42 Iris MarionYoung, Inclusion and Democracy,(Oxford: Oxford University Press, 2000), hal. 19.

${ }^{43}$ P. Levin dalam Mohd Azizuddin Mohd Sani dan Abubakar Eby Hara, Op. Cit.., hal 2.

${ }^{44}$ A. Gutman and D. Thompson, "Moral Conflict and Political Consensus. Ethics: An International, Journal of Social, Political and Legal Philosophy", Vol. 101 (1), 1990, hal. 5.

${ }^{45}$ Ibid.

${ }^{46}$ James Bohman dalam Mohd Azizuddin Mohd Sani dan Abubakar Eby Hara, loc. cit. 
mendengarkan orang lain, memperhatikan kekhawatiran orang lain dan menemukan beberapa kesamaan sehingga kompromi dapat dicapai.

Knight, Jhonson, dan Bohman menyatakan bahwa pemerintahan yang mendasarkan pada demokrasi deliberatif harus memberikan kesempatan yang adil bagi aktor non-negara "to have access to political influence on the political communication and decision making". ${ }^{47}$ Aksesibilitas terhadap proses politik tersebut bagi masyarakat sipil, pelaku ekonomi, dan masyarakat terkena dampak harus memuat prinsip-prinsip dasar demokrasi diantaranya adalah pemenuhan akses informasi.

Gerakan HAM turut memperkuat gerakan pemenuhan partisipasi ini. Partisipasi warga negara secara individu dan kelompok dalam pengambilan keputusan dan kebijakan yang mempengaruhinya merupakan hak asasi. ICCPR (International Convenant on Civil and Political Rights) melindungi hak tersebut sebagaimana tercantum pada Pasal 25(a) yang menjamin hak untuk berperan dalam kegiatan-kegiatan publik, secara langsung maupun dalam bentuk perwakilan yang dipilih secara bebas. Sejumlah deklarasi internasional, perjanjian dan traktat telah mengelaborasi hak atas partisipasi ini. Di bidang lingkungan, partisipasi tertuang dalam misalnya Prinsip 10 Rio dan Agenda 21 Pasal 23.2.

Terkait dengan partisipasi publik dalam perspektif HAM, hak asasi manusia terkait dengan lingkungan mencakup hak untuk menerima pemberitahuan awal atas resiko lingkungan dan hak atas Amdal, hak atas ganti rugi termasuk hak gugat untuk litigasi bagi kepentingan publik dan hak bagi ganti rugi yang efektif atas kerusakan lingkungan. ${ }^{48}$ Dengan demikian, hak atas partisipasi dapat dipenuhi apabila hak atas informasi telah terpenuhi. Pentingnya partisipasi publik dalam pembuatan keputusan lingkungan secara internasional telah diakui. Kurangnya partisipasi publik dalam pembuatan keputusan di bidang lingkungan telah menghasilkan strategi pembangunan yang berorientasi pada pertumbuhan ekonomi dan keuangan. Konsultasi global mengenai hak asasi dan hak atas pembangunan menyimpulkan bahwa strategi ekonomi ini telah gagal meraih keadilan sosial, hak asasi manusia telah diabaikan dan melalui de-personalisasi hubungan sosial, merusak keluarga atau komunitas serta hubungan ekonomi dan sosial. ${ }^{49}$

47 Andreas Klinke, Deliberative Democratization Across Borders: Participation And Deliberation In Regional Environmental Governance, (Elsevier Ltd., 2011), hal. 58.

48 Sharon Beder, Op. Cit., hal. 106.

49 Ibid. 


\subsection{Asimetri Informasi : \\ Akses Informasi sebagai Prasyarat Menuju Pendekatan Demokrasi Deliberatif}

Permasalahan lingkungan yang kompleks dan keterbatasan ilmu pengetahuan menuntut adanya proses dialog dalam pengambilan keputusan yang juga merupakan ciri utama dalam pemerintahan yang mengedepankan demokrasi deliberatif. Namun hal tersebut tidak bisa dilakukan secara baik apabila terjadi asimetri informasi, yaitu masing-masing pemangku kepentingan tidak memiliki informasi yang setara. Selain itu, informasi juga merupakan bagian dari hak asasi manusia yang diakui dalam konstitusi UUD NRI 1945. Oleh karena itu, keberadaan Negara menjadi penting untuk memastikan agar tidak terjadi asimetri informasi melalui pemenuhan akses informasi bagi masyarakat secara utuh, cepat, dan akurat.

Athony I. Ogus berpendapat ada dua kategori besar pengaturan tentang informasi agar tidak terjadi asimetri informasi. Pertama, pengaturan yang mewajibkan pihak yang menguasai informasi untuk membuka informasi tersebut kepada pihak lain. Kedua, pengaturan yang bertujuan untuk memastikan agar informasi yang disampaikan atau dibuka tersebut tidak salah (misleading). ${ }^{50}$

Informasi dapat merealisasikan hak asasi manusia, misalnya orang membutuhkan informasi untuk mengetahui bahwa hak-hak mereka terancam dan siapa pihak yang mengancam tersebut. Hak untuk tahu tidak hanya berdasarkan hak asasi tetapi juga pemerintah yang terbuka dan transparan untuk jalannya fungsi demokrasi yang baik. Hak untuk tahu sangat fundamental untuk memastikan akuntabilitas pemerintah dan sektor privat. ${ }^{51}$

Gerakan pemenuhan informasi lingkungan sudah muncul sejak agenda-agenda lingkungan hidup didorong dalam berbagai kebijakan nasional maupun internasional. Hal ini dipengaruhi pula oleh perkembangan teknologi yang semakin pesat. Gerakan pemenuhan informasi lingkungan berkembang secara luas pada tahun 1990-an dengan semakin meningkatnya tuntutan pemenuhan prinsip akses publik terhadap informasi lingkungan. Sebagai contoh "the Convention on Access to Information, Public Participation in Decision Making and Access to Justice in Environmental Matters" atau disebut Konvensi Aarhus. Konvensi tersebut ditandatangani oleh Komisi PBB untuk Eropa pada

50 Anthony I Ogus, Regulation: Legal Form and Economic Theory,(Hart Publishing, Oxford-Portland Oregon, 2004), hal. 121.

${ }^{51}$ Sharon Beder, Op. Cit., hal. 106. 
tahun 1998 guna mempromosikan akses untuk peningkatan partisipasi publik dalam pengambilan keputusan lingkungan dan kesadaran publik terhadap masalah-masalah lingkungan.

Tahun 1960-an adalah tonggak gerakan "revolusi lingkungan" yang mendefinisikan secara jelas hubungan antara regulasi dengan pengumpulan informasi untuk merespon permasalahn-permasalah lingkungan secara dini sebagai gerakan lingkungan modern. Salah satu tonggak tersebut adalah NEPA 1969. NEPA secara eksplisit mengikat politik lingkungan dengan informasi. Pelaksanaan dari NEPA tersebut adalah dikeluarkannya instrumen laporan tahunan tentang status lingkungan dan Amdal. Keduanya dapat diartikan sebagai instrumen informasi. NEPA juga mendefinisikan hubungan antara informasi dengan pihak yang berkepentingan (interested party). Hal ini dinyatakan dalam NEPA sebagai berikut:

"All agencies of the federal government shall ...(g) make available to States, counties, municipalities, institutions, and individuals, advice and information useful in restoring, maintaining, and enhancing the quality of the environment; $(h)$ initiate and utilise ecological information in the planning and development of resource-oriented projects;"52

Dorongan untuk memperhatikan informasi lingkungan dalam isu-isu lingkungan hidup terus berkembang selaras dengan konsep pembangunan berkelanjutan yang pertama dirilis melalui "Our Common Future" oleh World Commission on Environment and Development (WCED) pada tahun 1987. Seperti tertulis dalam laporan Burtland bahwa hukum saja tidak akan dapat menegakkan kepentingan bersama, yang oleh karena itu memerlukan partisipasi masyarakat yang lebih besar dalam pengambilan keputusan untuk dapat memberikan pengaruh terhadap lingkungan hidup. Sebuah argumen yang mendukung hal tersebut menyatakan bahwa demokrasi yang luas akan meningkatkan kualitas keputusan-keputusan tentang masalah lingkungan yang kompleks karena dengan mendengarkan berbagai macam suara, dimana termasuk didalamnya lingkungan itu sendiri, konsumen dan sudut pandang warga negara, pemerintah akan lebih memungkinkan untuk mengantisipasi masalah dan menyusun pertimbangan lingkungan ke dalam kebijakan. ${ }^{53}$ Pembangunan berkelanjutan mengakui bahwa walaupun proses demokrasi memiliki tantangan tersendiri, demokrasi tetap dipercaya merupakan hal yang

52 U.S. Congress, 1970 National Environmental Policy Act, pp. P.L. 91-190, S. 1075.

53 Neil Carter, The Politics of the Environment: Ideas, Activism, Policy, 2nd Edition, (Cambridge: Cambridge University Press, 2007), hal. 313. 
potensial untuk mendidik warga negara bersikap lebih memperhatikan lingkungan hidup dan meningkatkan kualitas pembuatan kebijakan lingkungan hidup. Hal ini bertolak belakang dengan modernisasi ekologi yang menempatkan kepercayaan yang lebih besar kepada inovasi di bidang Iptek dan mekanisme pasar dibandingkan dengan mekanisme demokrasi, untuk mewujdukan pembangunan berkelanjutan di dalam masyarakat. ${ }^{54}$

Wacana tersebut terus berkembang hingga puncaknya pada Konferensi Lingkungan Hidup dan Pembangunan di Rio de Janeiro pada bulan Juni 1992. Konferensi tersebut menghasilkan Deklarasi Rio dan Agenda 21 yang menegaskan keterkaitan akses terhadap informasi dengan pembangunan berkelanjutan. Prinsip 10 dalam deklarasi tersebut menyatakan:

"Environmental issues are best handled with the participation of all concerned citizens, at the relevant level. At the national level, each individual shall have appropriate access to information concerning the environment that is held by public authorities, and the opportunity to participate in decision-making processes. States shall facilitate and encourage public awareness and participation by making information widely available... " (UN, 1992b, Principle 10).

Agenda 21 memberikan perhatian khusus terhadap informasi. Dalam setiap bab dicantumkan bagian yang mengulas tentang pengumpulan data dan informasi. Selain itu, Bab 40 agenda tersebut mengulas khusus tentang "informasi dan pengambilan keputusan" yang dinyatakan sebagai berikut:

"In sustainable development, everyone is a user and provider of information considered in the broad sense. That includes data, information, appropriately packaged experience and knowledge. The need for information arises at all levels, from that of senior decision makers at the national and international levels to the grass-roots and individual levels. ..." (UN, 1992a)

Ada dua aspek penting dalam informasi lingkungan yang ditekankan pada kalimat diatas. Pertama, agenda tersebut menekankan peran khusus dari jenis-jenis informasi lingkungan. Kedua, perhatian khusus kepada akses publik terhadap informasi lingkungan. Baik Deklarasi Rio maupun Agenda 21 sebenarnya memastikan kedua hal tersebut yang dijelaskan pada bagian awal. Bagian III dari Agenda 21, diperuntukan untuk penguatan peran Major Groups yang mengintegrasikan kelompok perempuan, anak-anak dan pemuda, NGO,

${ }^{54}$ Ibid, hal. 316. 
masyarakat adat, petani, pemerintah daerah, pengusaha, dan sebagainya. Dalam pembukaan Deklarasi Rio dinyatakan:

"...Individuals, groups and organisations should have access to information relevant to environment and development held by national authorities, including information on products and activities that have or are likely to have a significant impact on the environment, and information on environmental protection measures..." (UN, 1992a, Chapter 23, sec 23.2)

Pembangunan dalam kebijakan lingkungan saat ini pada umumnya merujuk kepada Agenda 21 dan prinsip pembangunan berkelanjutan yang mendukung kerangka ecological modernitation. ${ }^{55}$ Blowers mencatat pembangunan berkelanjutan adalah salah satu prinsip ilmiah, tujuan politik, pelaksanaan sosial dan panduan moral. ${ }^{56}$ Dalam konteks ecological modernisation, akses publik terhadap informasi sebagai bagian dari prinsip umum dari prinsip partisipasi publik dalam pengambilan kebijakan. Namun beberapa pembangunan selama 1990-an menargetkan khusus hal ini. Dari sisi legal, beberapa konvensi secara khusus mengatur hal ini, seperti the European Council Directive 90/313/EEC, "Freedom of Access to Information on the Environment" and the Aarhus Convention (UN/ECE, 1998).

Politik lingkungan dan diskursus lingkungan berkembang dan mengalami perbedaan antara era awal (1960 an - awal 1970 an) dan sekarang. Pada era ini, konsep-konsep lingkungan tertanam dalam seluruh aktivitas manusia. Hal ini mengakibatkan kaburnya konsepsi tanggungjawab lembaga publik. Pada saat ini, setidaknya telah muncul prinsip yang memfokuskan pada inklusifitas dari pengambilan kebijakan. Prinsip ini berimplikasi pada informasi lingkungan. Informasi lingkungan dan data selalu dirasakan sebagai keharusan dalam pengambilan keputusan. Oleh karena itu, informasi lingkungan tersebut harus terbuka dan dapat diakses oleh seluruh pihak yang berkepentingan dalam pembuatan dan pelaksanaan keputusan. Sejak revolusi lingkungan pada tahun 1960-an hingga dipublikasikannya "Our Common Future", masalah lingkungan semakin memperlihatkan posisi dalam agenda politik. ${ }^{57}$ Tandatanda dari hal ini adalah bangkitnya kesadaran publik diberbagai tempat terhadap permasalahan lingkungan. Oleh karena itu tantangan bagi kebijakan

55 Blowers, A. (1997), Environmental Policy: Ecological Modernisation or the Risk Society?, Urban Studeis, 34(5-6), hal. 845-871.

56 A. Blowers, Ibid, hal. 846.

${ }^{57}$ Mc Cormick, Loc. Cit. 
kedepan salah satunya adalah bagaimana memperkuat akses publik terhadap informasi lingkungan.

\section{Potret Jaminan Hukum Pemenuhan Akses Informasi Lingkungan Hidup}

Jaminan akses informasi maupun partisipasi telah diatur mulai dari UUD NRI $1945^{58}$ hingga UU yang khusus memandatkan regulasi akses informasi yaitu UU KIP. Khusus di bidang perlindungan dan pengelolaan lingkungan hidup kita juga bisa mendapati regulasi ini pada UU PPLH.

UUD NRI 1945 memperlihatkan kaitan erat antara akses informasi dengan kebebasan mengemukakan pendapat sehingga kedua jaminan tersebut diatur dalam satu rumusan pasal yaitu Pasal 28 dengan penambahan huruf menjadi Pasal 28E dan Pasal 28F yang merupakan hasil amandemen kedua. ${ }^{59}$ Pengaturan secara khusus terkait dengan pemenuhan akses informasi dapat ditemukan dalam UU KIP. Bisa dibilang bahwa UU KIP mengatur tentang prosedural pemenuhan hak akses atas informasi. Pengaturan akses informasi di bidang lingkungan juga banyak ditemukan mulai dari UU PPLH ${ }^{60}$ hingga regulasi teknis dalam beberapa bidang seperti pengendalian pencemaran udara (PP 41/1999), pengelolaan kualitas air dan pengendalian pencemaran air (PP 82/2001), dan Analisis Mengenai Dampak Lingkungan Hidup (Amdal) dan izin lingkungan (PP 27/2012).

Terhadap berbagai regulasi tersebut, kita bisa memberikan catatan penting dengan mendasarkan pada prinsip dan pengaturan pada UU KIP maupun Konvensi Aarhus yang memberikan dasar pengaturan akses informasi lingkungan. Meskipun Indonesia tidak terikat dengan konvensi ini, namun prinsip pengaturannya bisa dikaji untuk memberikan masukan bagi pengaturan serupa di Indonesia. Adapun beberapa catatan penting terhadap pengaturan akses informasi lingkungan kita adalah sebagai berikut:

\section{NRI 1945}

${ }^{58}$ Lihat Pasal 28I ayat (4) dan ayat (5), Pasal 28, Pasal 28E ayat (3), dan Pasal 28F UUD

${ }^{59}$ Lihat Naskah Komprehensif Perubahan UUD 1945, (Jakarta: 2008), hal. 137. Pada Rapat Panitia Ad Hoc tanggal 7 Desember 1999 dibahas bahwa HAM cukup luas sehingga yang diatur dalam Amandemen UUD 1945 adalah HAM yang prioritas saja (Valina Singka Subekti-FUG).

${ }^{60}$ Lihat Ps. 2; Ps. 10 angka (8); Ps. 65 ayat (2); Ps. 68 huruf a ; Ps. 63 ayat (1) huruf u, Ps. 63 ayat (2) huruf o, dan Ps. 63 ayat (3) huruf l; Ps. 69 Ayat (1) huruf j; dan Ps. 113 UndangUndang tentang Pengelolaan Lingkungan Hidup, UU Nomor 23 Tahun 1997, LN No. 68 Tahun 1997, TLN No. 3699. 
1. Subyek yang dikenai kewajiban belum lengkap. Subyek hukum yang dikenai kewajiban untuk membuka informasi dalam UU KIP adalah badan publik yang didefinisikan dengan pendekatan sumber keuangan yaitu APBN/D, sumbangan masyarakat dan bantuan luar negeri. ${ }^{61}$ Definisi ini mempersulit rezim informasi lingkungan sebagai bagian dari rezim keterbukaan informasi yang diatur dalam UU KIP. Padahal informasi lingkungan tidak hanya dikuasai oleh pemerintah selaku badan publik melainkan juga terdapat pada lembaga swasta atau privat. Sebagai contoh dalam kasus longsornya Danau Wanagon, informasi peringatan dini dan informasi lainnya seperti besarnya kapasitas tailing dan kandungan B3 yang ada di dalamnya lebih memungkinkan untuk disampaikan oleh pelaku usaha daripada pemerintah. Terhadap pelanggaran peringatan dini dapat diancam dengan pidana sesuai dengan Pasal 52 UU KIP. Namun karena perusahaan bukan merupakan bagian dari badan publik berdasarkan UU KIP, maka ketentuan tentang kewajiban memberikan informasi serta merta dan ancaman sanksi pidana akibat pelanggaran kewajiban tersebut tidak dapat diterapkan dibawah rezim UU KIP.

Kemudian, meskipun UU PPLH mengatur kewajiban setiap orang untuk memberikan informasi namun peraturan pelaksananya lebih banyak mengatur pemerintah daripada pelaku usaha. Penyebutan pelaku usaha yang memiliki kewajiban juga masih sangat umum sehingga tidak dapat dibedakan apakah setiap pelaku usaha harus mempunyai standar yang sama atau tidak, misalnya pelaku usaha yang tidak wajib Amdal karena tidak memiliki dampak penting atau resiko besar apakah harus mengikuti kewajiban atau standar yang sama dengan pelaku usaha yang tidak wajib Amdal.

Sementara itu dalam Konvensi Aarhus, subyek yang dikenai kewajiban tidak hanya berdasarkan aliran pendanaan saja melainkan juga fungsi dan aktivitasnya yang berdampak terhadap publik. Artikel 2 Paragraf 2 Konvensi Aarhus menyatakan "Public authority means :(a) Government at national, regional and other level; (b) Natural or legal persons performing public administrative functions under national law, including specific duties, activities or services in relation to the environment; (c) Any other natural or legal persons having public

${ }^{61}$ Indonesia (d), Op. Cit., Ps. 1 angka (3) dan Indonesia (k), Op. Cit., Ps. 3 
responsibilities or functions, or providing public services, in relation to the environment, under the control of a body or person falling within subparagraphs (a) or (b) above; (d) The institutions of any regional economic integration organization referred to in article 17 which is a Party to this Convention. This definition does not include bodies or institutions acting in a judicial or legislative capacity."

2. Pemenuhan akses informasi tidak diatur dalam setiap tahapan kegiatan perlindungan dan pengelolaan lingkungan. Ketentuan untuk membuka informasi (mandatory disclosure) dan pencegahan untuk memberikan informasi yang menyesatkan (misleading information) tidak diatur mencakup semua tahapan mulai dari tahap pengambilan keputusan yang bersifat umum seperti penetapan kebijakan, standar, dan baku mutu hingga monitoring dan keputusan teknis pemberian izin, khususnya terkait dengan aspek resiko. Kondisi seperti ini ditemukan berbeda-beda antara satu peraturan dengan peraturan lainnya. Sebagai contoh, PP No. 82 Tahun 2001 tentang Pengelolaan Kualitas Air dan Pengendalian Pencemaran Air tidak mengatur secara rinci tentang pemenuhan akses informasi dalam perencanaan pendayagunaan air, pemantauan kualitas air, pemberian izin dan pengawasannya. Tidak utuhnya pengaturan seperti ini dapat mengakibatkan lemahnya pemenuhan informasi, khususnya terkait dengan resiko dan partisipasi masyarakat. Sebagai contoh dalam kasus dugaan pencemaran Teluk Buyat. Pada tahap awal perencanaan tidak banyak LSM lingkungan dan masyarakat yang memperoleh informasi secara memadahi, khususnya terkait dengan resiko penggunaan metode Sub-marine Tailing Disposal (STD). Perusahaan lebih proaktif dalam menyampaikan informasi untuk membalas informasi yang telah dipublikasikan oleh LSM lingkungan soal metode tersebut.

3. Tidak ada pengaturan tentang jenis-jenis informasi lingkungan dan aspeknya yang harus dibuka (standard content), khususnya tentang resiko lingkungan. Ketentuan yang ada belum mengatur tentang jenis-jenis informasi lingkungan secara rinci yang dapat menjelaskan tentang kelengkapan atau keutuhan informasi yang harus dibuka kepada publik beserta bentuk penyajiannya. Misalnya 
pengumuman terkait dengan permohonan izin tidak diatur lebih rinci informasi apa yang disajikan di dalamnya. Apakah hanya memuat nama perusahaan atau hingga lokasi dan kemungkinan dampak yang ada, di mana informasi secara lengkap dapat diperoleh, dan bagaimana masyarakat dapat meminta informasi yang lengkap termasuk resiko dari rencana kegiatan tersebut serta bagaimana menyampaikan saran atau masukan.

Konvensi Aarhus memberikan cakupan tentang informasi lingkungan lebih luas dan jelas. Informasi lingkungan mencakup "any information in written, visual, aural, electronic or any other material form on: (a) The state of elements of the environment, such as air and atmosphere, water, soil, land, landscape and natural sites, biological diversity and its components, including genetically modified organisms, and the interaction among these elements; (b) Factors, such as substances, energy, noise and radiation, and activities or measures, including administrative measures, environmental agreements, policies, legislation, plans and programmes, affecting or likely to affect the elements of the environment within the scope of subparagraph (a) above, and cost-benefit and other economic analyses and assumptions used in environmental decision-making; (c) The state of human health and safety, conditions of human life, cultural sites and built structures, inasmuch as they are or may be affected by the state of the elements of the environment or, through these elements, by the factors, activities or measures referred to in subparagraph (b) above."

4. Belum adanya standar pemenuhan akses informasi lingkungan. Beberapa regulasi lingkungan hidup di atas belum mengatur secara rinci tentang standar pemenuhan akses informasi yang mencakup keragaman media, standar content dari pengumuman, dan layanan permintaan informasi.

UU KIP sendiri masih mengatur hal ini secara umum, khususnya untuk standar pengumuman informasi. Untuk informasi yang wajib diumumkan secara berkala oleh pemerintah diatur setidaknya dengan menggunakan papan pengumuman dan situs. Bagaimana dengan perusahaan yang tidak tunduk dengan rezim UU KIP? Hal ini juga perlu mendapat perhatian agar perusahaan menggunakan media pengumuman yang tepat dan dapat dikontrol oleh pemerintah maupun masyarakat. 
Standar pemenuhan akses informasi ini sangat penting untuk memastikan adanya kemudahan akses bagi publik serta keutuhan dan akurasi informasi. Pengaturan seperti ini dapat diatur dalam petunjuk teknis atau standard operational procedure yang menjadi standar minimum bagi pemerintah dan pelaku usaha dalam mempublikasikan informasi lingkungan, khususnya tentang informasi resiko yang dihadapi oleh masyarakat terkait dengan kebijakan ataupun pelaksanaan suatu usaha atau kegiatan.

\section{Belum ada mekanisme penyelesaian sengketa bagi pelanggaran} informasi lingkungan. Mekanisme penyelesaian sengketa informasi lingkungan yang cepat dan sederhana merupakan salah satu aspek yang penting dalam mendorong pemenuhan akses informasi namun belum ada peraturan dibawah rezim UU PPLH yang mengatur hal ini. PERMEN LH No. 9 Tahun 2010 tentang Tata Cara Pengaduan dan Penanganan Pengaduan Akibat Dugaan Pencemaran dan/atau Perusakan Lingkungan Hidup hanya mengatur obyek sengketa mengenai dugaan terjadinya pencemaran atau perusakan lingkungan saja. ${ }^{62}$ Sengketa mengenai pelanggaran akses informasi

${ }^{62}$ Indonesia (m), Peraturan Menteri Lingkungan Hidup tentang Tata Cara Pengaduan Dan Penanganan Pengaduan Akibat Dugaan Pencemaran Dan/Atau Perusakan Lingkungan Hidup, Peraturan Menteri Lingkungan Hidup No. 9 Tahun 2010, Ps. 6 dan Ps. 9. Pasal 6 menyatakan: (1) Pengaduan secara tertulis sebagaimana dimaksud dalam Pasal 4 dapat disampaikan melalui antara lain: (a) surat; (b) surat elektronik; (c) faksimili; (d) layanan pesan singkat; dan/atau (e) cara lain sesuai dengan perkembangan ilmu pengetahuan dan teknologi; (2) Pengaduan tertulis sebagaimana dimaksud pada ayat (1) memuat informasi: (a) identitas pengadu yang paling sedikit memuat informasi nama, alamat, dan nomor telepon yang bisa dihubungi;(b) lokasi terjadinya pencemaran dan/atau perusakan lingkungan hidup; (c) dugaan sumber pencemaran dan/atau perusakan lingkungan hidup; (d) waktu terjadinya pencemaran dan/atau perusakan lingkungan hidup; dan (e) media lingkungan hidup yang terkena dampak. Sedangkan Pasal 9 menyatakan: (1) Kementerian Lingkungan Hidup melakukan penanganan pengaduan yang memenuhi kriteria: (a) usaha dan/atau kegiatan yang izin lingkungannya diterbitkan oleh Menteri; (b) usaha dan/atau kegiatan yang izin lingkungannya diterbitkan oleh Gubernur atau Bupati/Walikota tetapi Pemerintah menganggap terjadi pelanggaran yang serius; dan/atau (c) pengaduan pernah disampaikan kepada instansi yang bertanggungjawab di provinsi, tetapi tidak ditindaklanjuti dalam kurun waktu sebagaimana dimaksud dalam Pasal 8; (2) Instansi yang bertanggungjawab di provinsi melakukan penanganan pengaduan yang memenuhi kriteria: (a) usaha dan/atau kegiatan yang izin lingkungannya diterbitkan oleh gubernur; (b) usaha dan/atau kegiatan yang izin lingkungan hidup diterbitkan oleh bupati/walikota tetapi instansi yang bertanggung jawab di kabupaten/kota tidak melaksanakan pengelolaan pengaduan setelah dilakukan pembinaan oleh pemerintah provinsi; dan/atau (c) pengaduan pernah disampaikan kepada instansi yang bertanggungjawab di kabupaten/kota, tetapi tidak ditindaklanjuti dalam kurun waktu sebagaimana dimaksud dalam Pasal 8; (3) Instansi yang bertanggung jawab di 
maupun partisipasi tidak diatur secara jelas. Oleh karena itu, PERMEN LH No. 9 Tahun 2010 hanya mengatur persoalanpersoalan lingkungan yang dampaknya sudah terjadi atau dirasakan oleh masyarakat sehingga lembaga pengaduan ini lebih bersifat kuratif.

Jika sengketa informasi lingkungan dengan badan publik seperti KLH atau pemerintah provinsi dan daerah dapat diselesaikan melalui upaya keberatan kepada atasan, komisi informasi, dan kemudian ke pengadilan, sengketa informasi lingkungan dengan pelaku usaha tidak memiliki jalur penyelesaian sengketa yang didesain untuk itu kecuali dengan melakukan gugatan ke pengadilan seperti yang terjadi dalam studi kasus longsornya Danau Wanagon. Dari sisi kemudan akses keadilan, upaya penyelesaian sengketa melalui pengadilan terkadang tidak efektif karena hambatan pemahaman dan keterampilan teknis hukum dari masyarakat. Oleh karena itu, kehadiran lembaga penyelesaian sengketa baik di internal badan publik maupun di luar sangat diperlukan.

6. Ketentuan sanksi bagi pelanggaran akses informasi lingkungan yang lemah dan tidak konsisten. Sanksi bagi pelanggaran kewajiban pemenuhan akses informasi lingkungan tidak diatur secara komprehensif dan konsisten dalam UU PPLH:

(a) Sanksi administrasi dalam UU PPLH tidak mengatur bagi pelanggaran informasi. Sanksi administrasi dalam UU PPLH dikaitkan dengan pelanggaran terhadap izin lingkungan. ${ }^{63}$ Padahal dalam beberapa peraturan kewajiban bagi pelaku usaha untuk pemenuhan akses informasi atau sistem informasi tidak dikaitkan secara tegas dengan persyaratan izin lingkungan. Kemudian, bentuk sanksi administratif dalam UU PPLH adalah: (1) teguran tertulis; (2) paksaan pemerintah; (3) pembekuan izin lingkungan; dan (4) pencabutan izin lingkungan. Bentuk sanksi paksaan

kabupaten/kota melakukan penanganan pengaduan terhadap usaha dan/atau kegiatan yang izin lingkungannya diterbitkan oleh bupati/walikota.

63 Indonesia (a), Op. Cit., Ps. 76 ayat (1) menyatakan: Menteri, gubernur, atau bupati/walikota menerapkan sanksi administratif kepada penanggung jawab usaha dan/atau kegiatan jika dalam pengawasan ditemukan pelanggaran terhadap izin lingkungan. 
pemerintah diatur secara limitatif pada Pasal 80 UU PPLH dimana tidak menyebutkan sanksi berupa membuka informasi secara utuh dan akurat. ${ }^{64}$ Sedangkan penjatuhan sanksi berupa pembekuan dan pencabutan izin lingkungan hanya bisa dilakukan jika pelaku usaha/kegiatan tidak melaksanakan paksaan pemerintah. Jadi, penjatuhan sanksi administrasi atas pelanggaran pemenuhan akses informasi ini berpotensi tidak dapat diterapkan berdasar UU PPLH.

(b) Untuk sanksi pidana juga berpotensi tidak dapat diterapkan mengingat: 65

1. Tidak ada sanksi pidana untuk kewajiban membuka informasi (mandatory disclosure). Sanksi pidana dalam UU PPLH hanya mengatur tentang ketentuan misleading information, padahal dalam beberapa peraturan pelaksana tidak hanya mengatur tentang misleading information saja melainkan juga ketentuan mandatory disclosure; dan

${ }^{64} \mathrm{Ibid}$, Ps. 80 menyatakan:

(1) Paksaan pemerintah sebagaimana dimaksud dalam Pasal 76 ayat (2) hurufb berupa:

a) penghentian sementara kegiatan produksi;

b) pemindahan sarana produksi;

c) penutupan saluran pembuangan air limbah atau emisi;

d) pembongkaran;

e) penyitaan terhadap barang atau alat yang berpotensi menimbulkan pelanggaran;

f) penghentian sementara seluruh kegiatan; atau

g) tindakan lain yang bertujuan untuk menghentikan pelanggaran dan tindakan memulihkan fungsi lingkungan hidup.

(2) Pengenaan paksaan pemerintah dapat dijatuhkan tanpa didahului teguran apabila pelanggaran yang dilakukan menimbulkan:

a) ancaman yang sangat serius bagi manusia dan lingkungan hidup;

b) dampak yang lebih besar dan lebih luas jika tidak segera dihentikan pencemaran dan/atau perusakannya; dan/atau

c) kerugian yang lebih besar bagi lingkungan hidup jika tidak segera dihentikan pencemaran dan/atau perusakannya.

65 Ibid, Ps. 113 menyatakan: "Setiap orang yang memberikan informasi palsu, menyesatkan, menghilangkan informasi, merusak informasi, atau memberikan keterangan yang tidak benar yang diperlukan dalam kaitannya dengan pengawasan dan penegakan hukum yang berkaitan dengan perlindungan dan pengelolaan lingkungan hidup sebagaimana dimaksud dalam Pasal 69 ayat (1) huruf $j$ dipidana dengan pidana penjara paling lama 1 (satu) tahun dan denda paling banyak Rp1.000.000.000,00 (satu miliar rupiah)." 
2. Sanksi pidana dalam UU PPLH diatur secara limitatif hanya untuk informasi atau keterangan yang tidak benar/palsu/menyesatkan dalam rangka pengawasan dan penegakan hukum. Padahal pengawasan dan penegakan hukum hanya salah satu tahap saja dalam kegiatan perlindungan dan pengelolaan lingkungan hidup.

(c) Sanksi terhadap pelanggaran informasi atau penghambat informasi masih banyak diarahkan hanya kepada pelaku usaha. Padahal dalam beberapa ketentuan ditemukan kewajiban bagi pemerintah untuk membuka informasi lingkungan.

\section{Memperkuat Jaminan Akses Informasi Lingkungan Hidup: Suatu Rekomendasi}

\subsection{Penguatan norma pemenuhan akses informasi}

Penguatan jaminan akses informasi lingkungan hidup perlu diarahkan dengan menutup beberapa kelemahan penormaan yang secara umum ditemukan dalam beberapa regulasi di bidang lingkungan sebagaimana dijelaskan sebelumnya. Artinya beberapa penormaan di bawah ini dapat dipertimbangkan dalam setiap pembuatan aturan di bidang lingkungan hidup.

1. Subyek hukum. Pengaturan tentang siapa yang dikenai kewajiban untuk membuka informasi lingkungan perlu dirinci secara tegas. Pengaturan di bawah UU PPLH pada intinya menyebutkan setiap orang dan Pemerintah. Sedangkan pengaturan pada UU KIP menyebutkan badan publik dengan pendekatan aliran dana (APBN/D, sumbangan masyarakat, atau bantuan luar negeri). Contoh pengaturan subyek hukum secara rinci dapat ditemukan pada Konvensi Aarhus maupun Environmental Information Regulation (3391/2004) yang mencakup: (a) instansi pemerintah pusat, regional atau provinsi, dan daerah; (b) perorangan atau badan hukum yang melaksanakan fungsi administrasi publik, memiliki tanggungjawab khusus, menjalankan kegiatan atau fungsi, yang terkait dengan lingkungan; (c) setiap badan atau pihak yang berada dibawah kontrol poin (a) dan (b) dan memiliki tanggungjawab terkait dengan lingkungan hidup, melaksanakan fungsi sebagai pengawai publik yang 
terkait dengan lingkungan hidup dan yang menyediakan layanan masyarakat yang terkait dengan lingkungan hidup. ${ }^{66}$

Pengaturan tentang siapa yang berhak memperoleh informasi atau pemohon juga diperlukan untuk menjamin agar informasi lingkungan diperoleh oleh pihak yang berkepentingan. Perlu dihindari upaya-upaya pembatasan melalui pengaturan ini sebagaimana terjadi dalam UU KIP dimana pihak yang dapat menjadi pemohon adalah warga Negara Indonesia dan badan hukum Indonesia. Pengaturan tentang siapa yang memiliki akses perlu didasarkan pada pendekatan kepentingan (parties with interest). Pendefinisian yang luas akan memberikan jaminan yang luas pula. Definisi yang cukup luas dapat dilihat pada Keputusan Kepala Badan Pengendalian Dampak Lingkungan Hidup No. 08 tahun 2000 tentang Keterlibatan Masyarakat dan Keterbukaan Informasi dalam Proses Analisis Mengenai Dampak Lingkungan Hidup. Keputusan tersebut mendefinisikan siapa yang memiliki hak akses dengan 3 pendekatan: 1) masyarakat terkena dampak; 2) masyarakat yang berkepentingan; 3) pemerhati lingkungan. ${ }^{67}$

2. Prinsip pemenuhan akses informasi. Pengaturan tentang prinsip atau asas hukum tentang pemenuhan akses informasi diperlukan sebagai nilai dasar dari ketentuan pemenuhan akses informasi lingkungan. Prinsip hukum pemenuhan akses informasi juga berfungsi sebagai dasar pengambilan keputusan maupun penyelesaian sengketa atas pelaksanaan peraturan dalam rangka pemenuhan akses informasi lingkungan. Beberapa prinsip hukum yang perlu diatur dapat disesuaikan dengan prinsip pemenuhan akses informasi secara umum maupun yang telah tercantum dalam UU KIP. Tujuh Prinsip Umum Keterbukaan Informasi Publik yang perlu dipertimbangkan adalah: 68

a) Adanya jaminan hak yang komprehensif meliputi hak untuk melihat dan memeriksa (right to inspect), hak untuk mendapat salinan dokumen/akses pasif (right to obtain the copy), hak untuk diinformasikan/akses aktif (right to be informed), hak untuk menyebarluaskan informasi (right to disseminate).

b) Permintaan informasi tanpa memerlukan alasan

${ }^{66}$ Convention on Access to Information, Public Participation in Decision-Making and Access to Justice in Environmental Matters (Aarhus, Denmark: 25 June 1998), Article 2, dan Chapter 1 Environmental Information Regulation (3391/2004)

${ }^{67}$ Indonesia (i), Op. Cit., Bab I Subbab 1.3.

68 Henri Subagiyo dkk, Op. Cit., hal 71-82. Lihat pula Modul Pelatihan 3 Akses, (Jakarta: Indonesian Center for Environmental Law, 2010) hal 51. Lihat pula www. Article19.org diakses pada 8 September 2012. 
c) Akses maksimal dengan pengecualian terbatas (Maximum Access Limited Exemption). Hal ini diwujudkan dengan: a) pengecualian harus didasarkan pada kehati-hatian melalui proses uji konsekuensi (consequential harm test) dan uji kepentingan publik yang lebih besar (balancing public interest test); b) pemberlakuan status kerahasiaan harus mempunyai batas waktu (tidak bersifat permanen) sepanjang pertimbangan uji konsekuensi dan uji kepentingan publik terus tetap diberlakukan; c) ruang lingkup badan publik tidak terbatas pada institusi Negara tetapi juga di luar Negara yang memiliki dampak pada kepentingan publik.

d) Akses informasi harus bersifat murah, cepat, utuh, akurat, dapat dipercaya dan tepat waktu.

e) Adanya sistem pengelolaan informasi dan pelayanan informasi yang meliputi sistem pengumpulan dan produksi maupun penyebarluasan informasi.

f) Penyelesaian sengketa informasi secara cepat, murah, kompeten, dan independen melalui proses konsensual maupun ajudikatif.

g) Ancaman hukuman bagi pihak-pihak yang menghambat akses informasi dan perlindungan bagi whistle blower.

3. Jenis Informasi. Cakupan jenis informasi lingkungan perlu diatur mengingat tidak semua paraturan perundang-undangan lingkungan mendefinisikan hal ini secara jelas. ${ }^{69}$ Cakupan informasi lingkungan yang perlu dipertimbangkan untuk diatur antara lain:

${ }^{69}$ Convention on Access to Information, Public Participation in Decision-Making and Access to Justice in Environmental Matters (Aarhus, Denmark: 25 June 1998), Article 2. Konvensi Aarhus mendefinisikan cakupan informasi lingkungan sebagai berikut: "Informasi Lingkungan Hidup" berarti setiap informasi tertulis, visual, aural, dalam bentuk elektronik atau bentuk material lainnya tentang: (a) Bentuk elemen lingkungan hidup seperti udara dan atmosfer, air, tanah, lahan, lanskap dan situs alami termasuk lahan basah, pesisir dan area laut, keanekaragaman biologi dan komponen-komponennya, termasuk organisme yang secara genetis dimodifikasi dan interaksi antara elemen-elemen tersebut; (b) Faktor-faktor yaitu substansi, energi, kebisingan, radiasi, aktivitas atau upaya, termasuk upaya administratif, perjanjian lingkungan hidup, kebijakan, legislasi, rencana dan program yang mempengaruhi atau mungkin mempengaruhi elemen-elemen lingkungan hidup yang disebutkan pada butir (a) di atas, dan biaya serta analisis ekonomi lainnya serta asumsi yang digunakan dalam pengambilan keputusan lingkungan hidup; (c) Kondisi keamanan dan kesehatan, kondisi kehidupan manusia, situs kebudayaan dan struktur bangunan sebagaimana mereka atau sebagaimana mereka dapat dipengaruhi oleh keadaan elemen lingkungan hidupatau melalui elemen tersebut, oleh faktor-faktor, aktivitas atau upaya yang 
a) Informasi terkait dengan elemen lingkungan hidup seperti udara dan atmosfer, air, tanah, lahan, lanskap dan situs alami termasuk lahan basah, pesisir dan area laut, keanekaragaman hayati dan komponenkomponennya, termasuk organisme yang secara genetis dimodifikasi dan interaksi antara elemen-elemen tersebut;

b) Informasi terkait dengan materi, energi, zat kimia, kebisingan, radiasi, aktivitas atau upaya, termasuk upaya administrasi, perjanjian lingkungan hidup, kebijakan, legislasi, rencana dan program yang mempengaruhi atau mungkin mempengaruhi elemen-elemen lingkungan hidup di atas, dan anggaran atau biaya serta analisis ekonomi lainnya serta asumsi, resiko atau pertimbangan yang digunakan dalam pengambilan keputusan lingkungan hidup;

c) Informasi terkait kondisi keamanan dan kesehatan, kondisi kehidupan manusia, situs kebudayaan dan struktur bangunan yang dipengaruhi atau mempengaruhi keadaan elemen lingkungan hidup;

d) Informasi terkait dengan laporan pelaksanaan legislasi lingkungan hidup, pengambilan dan pelaksanaan keputusan (kebijakan, aturan pelaksanaan, dan izin), hasil pemantauan lingkungan hidup, pengawasan, dan penegakan hukum.

e) Informasi terkait dengan kondisi darurat lingkungan hidup yang mempengaruhi elemen-elemen lingkungan maupun manusia.

disebutkan di subparagraf (b) di atas. Lihat pula Chapter 1 Environmental Information Regulation (No.3391/2004) mendefinisikan "informasi lingkungan hidup" memiliki arti yang sama dengan Pasal 2 (1) dari Direktif, yaitu setiap informasi tertulis, visual, aural, elektronik atau bentuk material lainnya pada: (a) Bentuk elemen lingkungan hidup seperti udara dan atmosfir, air, tanah, lahan, lanskap dan situs alami termasuk lahan basah, pesisir dan area laut, keanekaragaman biologi dan komponen-komponennya, termasuk organisme yang secara genetis dimodifikasi dan interaksi antara elemen-elemen tersebut; (b) Faktor-faktor yaitu substansi, energi, kebisingan, radiasi atau limbah, termasuk limbah radio aktif, emisi, gas buang dan pembuangan ke lingkungan hidup, mempengaruhi atau mungkin mempengaruhi elemen-elemen lingkungan hidup yang disebutkan pada butir (a); (c) Upayaupaya (termasuk upaya administratif), seperti kebijakan, legislasi, rencana, program, perjanjian lingkungan hidup dan aktivitas-aktivitas yang mempengaruhi atau kemungkinan dapat mempengaruhi elemen-elemen dan faktor yang disebutkan di poin (a) dan (b) juga upaya atau kegiatan yang dirancang untuk melindungi elemen-elemen tersebut; (d) Laporan pelaksanaan legislasi lingkungan hidup; (e) Biaya-keuntungan dan analisa ekonomi atau asumsi lainnya yang digunakan dalam kerangka kerja upaya dan aktivitas yang disebutkan di poin (c); dan (f) Kondisi keamanan dan kesehatan manusia, termasuk kontaminasi rantai makanan, dimana relevan, kondisi kehidupan manusia, situs kebudayaan dan struktur bangunan sebagaimana mereka adanya atau sebagaimana mereka dapat dipengaruhi oleh keadaan elemen lingkungan hidup sesuai yang disebutkan di poin (a) atau melalui elemen tersebut sebagaimana disebutkan di poin (b) dan (c). 
Jika dikaitkan dengan prinsip keterbukaan informasi, pengaturan tentang jenis-jenis informasi lingkungan di atas bukanlah bersifat limitatif, artinya informasi lingkungan selain dari yang disebutkan pada daftar jenis informasi di atas harus tetap dapat diakses sepanjang bukan termasuk informasi yang rahasia. Pengaturan tentang jenis-jenis informasi lingkungan di atas dapat mempermudah pengelolaan sistem informasi.

4. Standar minimum. Peraturan perundang-undangan perlu mengatur tentang standar pelaksanaan pemenuhan akses informasi sebagai acuan bagi pelaksana maupun masyarakat yang berkepentingan atas informasi lingkungan. Standar yang perlu diatur tersebut merupakan standar minimum yang harus diatur lebih lanjut dalam Standard Operational Procedure (SOP) pihak yang memiliki kewajiban. Untuk memastikan agar setiap pengemban kewajiban memiliki standar, bagi pelaku usaha kewajiban memiliki SOP perlu dijadikan sebagai syarat prosedur permohonan izin lingkungan. Hal ini dimungkinkan berdasarkan Peraturan Pemerintah No. 27 Tahun 2012 tentang Izin Lingkungan dimana pada Pasal 48 Ayat (1) huruf b dinyatakan bahwa izin lingkungan harus memuat persyaratan dan kewajiban yang ditetapkan oleh Menteri, gubernur, atau bupati/walikota. Sedangkan bagi pemerintah telah diatur dalam UU KIP dan peraturan pelaksananya. Adapun standar minimum yang perlu diatur, antara lain: (a) sistem pengumpulan dan pendokumentasian (pengarsipan) informasi; (b) sistem penyebarluasan informasi baik aktif maupun pasif; (c) standar penyajian termasuk kelengkapan isi dari informasi; (d) standar pengelolaan pengaduan atau sengketa secara internal.

5. Mekanisme pengaduan dan penyelesaian sengketa. Salah satu kelemahan mendasar dari peraturan tentang informasi lingkungan adalah tidak adanya prosedur pengaduan dan penyelesaian sengketa yang memadai. Prosedur pengaduan dan penyelesaian sengketa lingkungan yang diatur dalam PERMEN LH No. 9/2010 tentang Tata Cara Pengaduan dan Penanganan Pengaduan Akibat Dugaan Pencemaran dan/atau Perusakan Lingkungan Hidup hanya menitikberatkan pada dugaan pencemaran atau perusakan dengan mendasarkan pada izin lingkungan. Selain itu, independensi lembaga ini juga layak untuk dipertimbangkan mengingat lembaga ini berada dibawah pemerintah sebagai regulator maupun pengambil keputusan sehingga lebih berupa lembaga keberatan (upaya administrasi) dan juga memungkinkan terjadi conflict of interest. Mekanisme pengaduan dan penyelesaian sengketa dapat diatur dengan dua opsi, yaitu:

a) Menggunakan lembaga pengaduan dan penyelesaian sengketa lingkungan di bawah pemerintah. Lembaga ini dapat dipertahankan 
namun perlu direvitalisasi dengan: (a) memperluas obyek sengketa agar tidak hanya dugaan terjadinya pencemaran atau perusakan lingkungan saja melainkan juga sengketa informasi lingkungan; (b) mempertimbangkan orang-orang yang memiliki kapasitas dan integritas yang baik untuk duduk didalamnya (ad hoc) dan diberi wewenang untuk memeriksa dan memutuskan sengketa informasi lingkungan.

b) Memberikan wewenang kepada Komisi Informasi sebagai lembaga yang mengelola pengaduan dan penyelesaian sengketa informasi lingkungan. Hal ini dapat dilakukan dengan memberikan wewenang kepada Komisi Informasi untuk: (a) menyelesaikan sengketa dan mengambil keputusan atas pelanggaran informasi lingkungan, tidak hanya menyangkut badan publik di bawah UU KIP melainkan juga pelaku usaha dibawah UU PPLH; (b) memerintahkan kepada pemerintah agar menjatuhkan sanksi administrasi apabila putusan untuk memenuhi kewajiban dalam membuka informasi lingkungan tidak dilaksanakan oleh pelaku usaha.

6. Sanksi. Pengaturan sanksi dapat diarahkan kepada sanksi pidana maupun administrasi. Meskipun terbatas, sanksi pidana dapat merujuk kepada sanksi bagi tindakan yang mengakibatkan misleading information yang dikaitkan dengan pengawasan dan penegakan hukum sebagaimana diatur dalam Pasal 113 UU PPLH..$^{70}$ Apabila kita kaji, tindakan pengawasan dan penegakan hukum merupakan salah satu kegiatan saja dalam upaya perlindungan dan pengelolaan lingkungan hidup. Agar pasal ini dapat didayagunakan, maka harus diatur bahwa kewajiban pelaku usaha untuk membuat SOP informasi lingkungan adalah sebagai syarat prosedural permohonan izin lingkungan. Dengan demikian pelaksanaan dari SOP tersebut merupakan bagian dari ketaatan pelaku usaha atas izin lingkungan yang harus diawasi. Hal ini akan memperkuat aktivitas pengawasan sebagai salah satu aktivitas untuk

70 Indonesia (a), Op. Cit., Ps. 113. “Setiap orang yang memberikan informasi palsu, menyesatkan, menghilangkan informasi, merusak informasi, atau memberikan keterangan yang tidak benar yang diperlukan dalam kaitannya dengan pengawasan dan penegakan hukum yang berkaitan dengan perlindungan dan pengelolaan lingkungan hidup sebagaimana dimaksud dalam Pasal 69 ayat (1) huruf j dipidana dengan pidana penjara paling lama 1 (satu) tahun dan denda paling banyak Rp1.000.000.000,00 (satu miliar rupiah)." Pasal 55 UU KIP mengatur: "Setiap Orang yang dengan sengaja membuat Informasi Publik yang tidak benar atau menyesatkan dan mengakibatkan kerugian bagi Orang lain dipidana dengan pidana penjara paling lama 1 (satu) tahun dan/ atau denda paling banyak Rp5.000.000,00 ( lima juta rupiah) ." 
mengumpulkan informasi sehingga informasi hasil pengawasan dapat dipublikasikan.

Demikian juga untuk pengaturan sanksi administrasi. Oleh karena pengaturan sanksi administrasi dalam UU PPLH hanya ditekankan pada pelanggaran izin lingkungan, ${ }^{71}$ maka pengaturan yang mengaitkan SOP informasi lingkungan sebagai salah satu syarat prosedural permohonan izin lingkungan dapat dijadikan dasar untuk menjatuhkan sanksi administrasi.

\section{Daftar Pustaka}

Annan, Kofi. 2000. We the People: the Role of the UN in the 21st Century. http://iefworld.org/UNSGmill.htm

Achmad Santosa, Mas. 2001. Hukum Lingkungan dan Good Governance. Jakarta: Indonesian Center for Environmental Law.

Beder, Sharon. 2006. Environmental Principles and Policies. London: Earthscan.

\section{${ }^{71}$ Ibid, Ps. 76:}

(1) Menteri, gubernur, atau bupati/walikota menerapkan sanksi administratif kepada penanggung jawab usaha dan/atau kegiatan jika dalam pengawasan ditemukan pelanggaran terhadap izin lingkungan.

(2) Sanksi administratif terdiri atas:

a. teguran tertulis;

b. paksaan pemerintah;

c. pembekuan izin lingkungan; atau

d. pencabutan izin lingkungan.

Pasal 80 UU PPLH:

(1) Paksaan pemerintah sebagaimana dimaksud dalam Pasal 76 ayat (2) huruf b berupa:

a. penghentian sementara kegiatan produksi;

b. pemindahan sarana produksi;

c. penutupan saluran pembuangan air limbah atau emisi;

d.pembongkaran;

e. penyitaan terhadap barang atau alat yang berpotensi menimbulkan pelanggaran;

f. penghentian sementara seluruh kegiatan; atau

g.tindakan lain yang bertujuan untuk menghentikan pelanggaran dan tindakan memulihkan fungsi lingkungan hidup.

(2) Pengenaan paksaan pemerintah dapat dijatuhkan tanpa didahului teguran apabila pelanggaran yang dilakukan menimbulkan:

a. ancaman yang sangat serius bagi manusia dan lingkungan hidup;

b. dampak yang lebih besar dan lebih luas jika tidak segera dihentikan pencemaran dan/atau perusakannya; dan/atau

c. kerugian yang lebih besar bagi lingkungan hidup jika tidak segera dihentikan pencemaran dan/atau perusakannya. 
Blowers, Andrew. 1997. "Environmental Policy: Ecological Modernisation or the Risk Society?" Urban Studies, Vol. 34, 1997.

Boer, Ben. 1995. “Institutionalizing Ecologically Sustainable Development: the Role of National State, and Local Governments in Translating Grand Strategy into Action," Willamette Law Review, Vol. 31 Issue 31, 1995.

Briggs, D., C.C. Park, et.al. (Ed.). 1986. Environmental Problems and Policies in the European Community, In Environmental Policies: an International Review.

C. Wallen, C. History of "Earthwatch". http://www.unep.ch/ earthw/History.htm

Carrand, W. dan A. Hartnett. 1996. Education and the Struggle for Democracy: The Politics of Educational Ideas. Buckingham: Open University Press.

Carter, Neil. 2007. The Politics of the Environment: Ideas, Activism, Policy, 2nd Edition. Cambridge: Cambridge University Press.

Cheema, G. Shabbir. 2000. "Good Governance: A Path to Poverty Eradication", The Human Development Magazine, No. 1, Maret 2000.

Cotgrove, Stephen. 1975. “Technology, Rationality and Domination," Social Studies of Science, Vol. 5 Issue (1), Februari 1975.

Dahl, R. 2000. “A Democratic Paradox," Political Science Quarterly. Vol. 115, No. 1. $38,2000$.

Ecologically Sustainable Development Steering Committee of Australia. 1992. National Strategy for Ecologically Sustainable Development. Canberra: Council of Australia Government.

Farrelly, Colin. 2004. Deliberative Democracy. An Introduction to Contemporary Political Theory. London: Sage Publications.

Fischer, Frank (1). 2000. Citizen, Experts, and the Environment : the Politics of Local Knowledge. London: Duke University Press.

(2). 2000. Science and Politics in Environmental Regulation: The Politicization of Expertise. London: Duke Univeristy Press.

Functowicz, Silvio dan Jerome Ravetz. Post Normal Science: Environmental Policy under Conditions of Complexity. http:/ / www.nusap.net/ sections.php?op=viewarticle\&artid=13

Functowicz, Silvio, et.al. 1999. Information Tools for Environmental Policy Under conditions of Complexity. Copenhagen: European Environment Agency.

Gutman, A. dan D. Thompson. 1990. “Moral Conflict and Political Consensus. Ethics: An International Perspective", Journal of Social, Political and Legal Philosophy, Vol. 101 Issue (1), 1990. 
Harding, R. dan E. Fisher. 1999. "Ignorance, Sustainability And The Precautionary Principle: Towards An Analytical Framework," Perspectives on the Precautionary Principle. Sydney: The Federation Press, 1999.

Indonesia (1). Keputusan Kepala Bapedal No. 08 Tahun 2000 tentang Keterlibatan Masyarakat dan Keterbukaan Informasi dalam Proses Analisis Mengenai Dampak Lingkungan Hidup.

(2). Keputusan Kepala Bapedal No. Kep-107/Bapedal/11/1997tentang Pedoman Teknis Perhitungan dan Pelaporan Serta Informasi Indeks Standar Pencemar Udara.

(3). Peraturan Komisi Informasi No. 1 Tahun 2010 tentang Standar Layanan Informasi Publik, BN Tahun 2010.

(4). Peraturan Menteri Negara Lingkungan Hidup No. 09 Tahun 2010 tentang Tata Cara Pengaduan Akibat Dugaan Pencemaran dan/atau Perusakan Lingkungan Hidup.

(5). Indonesia. Peraturan Menteri Negara Lingkungan Hidup No. 6 Tahun 2011 tentang Pelayanan Informasi Publik di Kementerian Lingkungan Hidup.

(6). Peraturan Menteri Negara Lingkungan Hidup No. 8 Tahun 2006 tentang Pedoman Penyusunan Analisis Mengenai Dampak Lingkungan Hidup.

(7). Peraturan Pemerintah tentang Izin Lingkungan. PP No. 27 Tahun 2012, TLN No. 5285.

(8). Peraturan Pemerintah tentang Pengelolaan Kualitas Air dan Pengendalian Pencemaran Air, PP No. 82 Tahun 2001, TLN No. 4161.

(9). Peraturan Pemerintah tentang Pengendalian Pencemaran Udara. PP Nomor 41 Tahun 1999. LN No. 86 Tahun 1999, TLN No. 3853.

Tahun 1945.

(10). Perubahan ke-IV Undang-Undang Dasar Republik Indonesia

(11). Undang-Undang tentang Keterbukaan Informasi Publik. UU Nomor 14 Tahun 2008, LN No. 61 Tahun 2008, TLN No. 4846.

(12). Undang-Undang tentang Pengelolaan Lingkungan Hidup.UU No. 23 Tahun 1997, LN No. 68 Tahun 1997, TLN No. 3699.

(13). Undang-Undang tentang Perlindungan dan Pengelolaan Lingkungan Hidup. UU No. 32 Tahun 2009, LN No. 140 Tahun 2009, TLN No. 5059. 
Indonesian Center for Environmental Law dan World Resources Institute. 2012. Temuan Sementara: Strengthening the Right to Information to Improve Public Health and Wellbeing (SHRIMP). Oktober 2012. Jakarta: ICEL.

Indonesian Center for Environmental Law. 2011. Catatan Akhir Tahun 2011. Jakarta: ICEL, 28 Desember 2011.

Indrati, Maria Farida. 1998. Ilmu Perundang-undangan: Dasar-Dasar dan Pembentukannya. Jakarta: Kanisius.

International Union for Conservation of Nature (IUCN). 1991. Caring for the Earth: A Strategy for Sustainable Living. Gland: IUCN.

Kementerian Lingkungan Hidup, Pusat Sarana Pengendalian Dampak Lingkungan. 2004. Laporan Hasil Pemantauan Kualitas Lingkungan di Derah Pertambangan PT. NMR. Jakarta: Pusarpedal KLH.

Kementerian Lingkungan Hidup (1). 2000. Notulensi Hasil Pertemuan Bapedal, Departemen Pertambangan dan Energi, dan Departemen Eksplorasi Laut dan Perikanan, tanggal 11 April 2000.

(2). 2002. Data Arsip yang Berkaitan Dengan PT. Newmont Minahasa Raya: 1994 - 2002.

(3). 2004. Laporan Penelitian: Penanganan Dugaan Kasus Pencemaran dan/atau Perusakan Lingkungan Hidup di Desa Buyat Pantai dan Desa Ratatotok Kecamatan Ratatotok Timur, Kabupaten Minahasa Selatan, Provinsi Sulawesi Utara. Jakarta: Kementerian Lingkungan Hidup RI.

Klinke, Andreas. 2011. Deliberative Democratization Across Borders: Participation And Deliberation In Regional Environmental Governance. Amsterdam: Elsevier, Ltd.

Leiss, William. 1975. "Ideology and Science," Social Studies of Science, Vol. 5 Issue (2), May 1975.

Lofgren, Karl-Gustaf, Torsten Persson, dan Jorgen W. Wibull. 2002. “Market with Asymmetric Information: The Contribution of George Akerlof, Michael Spence and Joseph Stiglittz," The Scandinavian Journal of Economics, Vol. 104 No. 2, Juni 2002.

Mahkamah Konstitusi Republik Indonesia. 2008. Naskah Komprehensif Perubahan UUD 1945. Jakarta: MKRI.

McCormick, J. 1995. The Global Environment Movement. Chichester: John Wiley \& Sons.

McGrath, Patricia. 1998. Discharge Permitting and Environmental Assessment Issues Associated with Submarine Tailing Disposal for the Alaska-Juneau Mine Project. Washington D.C.: USEPA. 
Murharjanti, Prayekti, et.al. Menutup Akses Menuai Bencana (Potret Pemenuhan Akses Informasi, Partisipasi, dan Keadilan dalam Pengelolaaan Lingkungan Hidup dan Sumber Daya Alam di Indonesia), Cet. I, (Jakarta: ICEL, 2008).

Ogus, Anthony I. 2004. Regulation: Legal Form and Economic Theory. Oxford: Hart Publishing.

Petkova, Elena. et. al. 2002. Closing the Gap: Information, Participation, and Justice in Decision Making for the Environment. http://pdf.wri.org/closing_the_gap.pdf

Sani, Moh. Azizuddin dan Abubakar Eby Hara. 2002. Deliberative Democracy in Malaysia and Indonesia: A Comparison. Sintok: University Utara Malaysia.

Stirling, Andy dan David Gee. 2002. Science, Precoaution, and Practice, Public Health Report, Vol. 117, Nov - Des 2002.

Subagiyo, Henri, et.al. (1). 2009. Anotasi Undang-Undang Nomor 14 Tahun 2008 tentang Keterbukaan Informasi Publik. Jakarta: ICEL.

(2). 2010. Modul Pelatihan 3 Akses. Jakarta: ICEL.

Unit Kerja Presiden Bidang Pengawasan dan Pengendalian Pembangunan (UKP-PPP). 2011. Laporan Tim Open Government Indonesia, diluncurkan pada Agustus 2011. Jakarta: UKP4.

United Nations Development Programme (UNDP). 2000. Human Development Report 1999. http://hdr.undp.org/en/media/HDR_1999_EN.pdf

United Nations Economic and Social Commission for Asia and the Pacific (UNESCAP). What is Good Governance? http://www.unescap.org/huset/gg/governance.htm

United Nations Economic Comission for Europe (UNECE). What is Aarhus Convention? http://ec.europa.eu/environment/aarhus/

Wibisana, Andri G. 2011. “Konstitusi Hijau Perancis: Komentar atas Asas Kehati-hatian dalam Piagam Lingkungan Perancis 2004," Jurnal Konstitusi, Vol. 8 Issue (3), Juni 2011.

World Bank. 1992. Governance and Development. Washington D.C.: World Bank.

Young, Iris Marion. 2000. Inclusion and Democracy. Oxford: Oxford University Press. 